РЕЙКІН

Віталій Самсонович

Vitaliyreikin@gmail.com

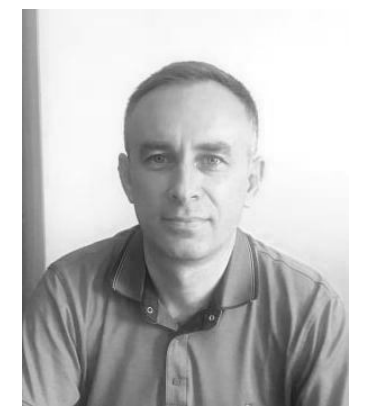

д.е.н., дочент, професор

кафедри, Волинський

національний університет

імені Лесі Українки
УДК 001.89

\section{RESEARCH METHODOLOGY IN ECONOMICS}

\section{МЕТОДОЛОГІЯ ДОСЛІДЖЕНЬ В ЕКОНОМІЧНІЙ НАУЦІ}

\author{
DOI: https://doi.org/10.37634/efp.2020.12(3).1
}

REIKIN Vitalii Samsonovych - Doctor of Economics, Associate Professor, Professor of department, Volyn National University after Lesia Ukrainka

Introduction. Some methodological provisions need to be modified according to the realities of existing practice and be verified according to the possibilities of their application in economic phenomena and processes study. Theoretical analysis of methodological principles, their comparison and generalization were used during investigation.

The purpose of the paper is to study basic methodological prerequisites and principles in economic research.

Results. Analyzing and summarizing the achievements of Nobel laureates, the methodological problems of limited rationality, information asymmetry and opportunistic behavior of economic agents are considered. Modern mainstream in economic research corresponds to binary paradigm of neoclassicism and neoinstitutionalism, which are based on two common elements of the "core": methodological individualism and "economic man" conception (homo economicus). The focus of the enterprises on maximizing profitability, and households - on benefits, is an axiom of neoclassicism, which implies significant requirements for information quantity and quality. At the same time, rational choice is accompanied by situations of uncertainty and varying degrees of risk regarding such activities consequences. The advantages of the institutional direction as the closest to the real conditions of economic entities market activity are substantiated. A specific feature of neoinstitutional approach is modification of neoclassical paradigm due to preserving basic preconditions of its "core" and partial transformation of "protective shell" into more perfect, realistic principles. In economics, the most significant is methodological combination of "semi-strong" limited rationality with a "strong" form of opportunistic behavior.

Conclusions. Thanks to introducing modified preconditions and methodological principles into neo-institutionalism, it became possible to improve the analysis of economics and to apply interdisciplinary research in combination with the approaches of other branches of science.

$$
* * *
$$

Окремі методологічні положення потребують модифікачії до реалій існуючої практики та верифікації стосовно можливостей їх застосування у дослідженні економічних явищ і прочесів. Під час проведення дослідження використано теоретичний аналіз методологічних принципів, їх порівняння та узагальнення.

Мета публікації полягає у дослідженні базових методологічних передумов та принципів в наукових дослідженнях економічної галузі.

Аналізуючи та узагальнюючі досягнення Нобелівських лауреатів, розглянуто методологічні проблеми обмеженої рачіональності, інформачійної асиметрії та опортуністичної поведінки економічних агентів. Сучасний мейнстрим 6 економічних дослідженнях відповідає бінарній парадигмі неокласицизму та неоінституціоналізму які трунтуються на двох спільних елементах «ядра»: методологічний індивідуалізм та концепиія «економічної людини» (hoто есопотісиs). Спрямованість підприємств на максимізаиію прибутковості, а домогосподарств - корисності, - аксіома неокласииизму, яка передбачає суттєві вимоги до кількості та якості інформачії. Водночас рачіональний вибір супроводжується ситуаціями невизначеності та різного ступеня ризику стосовно наслідків такої діяльності. Обтрунтовано переваги інститучіонального напряму як найбільш наближеного до реальних умов ринкової діяльності господарюючих суб'єктів. Специфічною особливістю неоінституиіонального підходу є модифікація неокласичної парадигми за рахунок збереження основних передумов ї̈ «ядра» та часткова трансформачія «захисної оболонки» на більш досконалі, реалістичні принципи. $B$ економічній науці найбільш суттєвим є методологічне поєднання «напівсильної» обмеженої рачіональності із «сильною» формою опортуністичної поведінки. Завдяки введенню в неоінституціоналізм модифікованих передумов та методологічних принципів з'явилася можливість удосконалення аналізу економічної науки та застосування міждисциплінарного досліджень у поєднанні з підходами інших галузей науки.

Keywords: methodology, neoclassicism, neoinstitutionalism, limited rationality, risk

Ключові слова: методологія, неокласицизм, неоінституцฺіоналізм, обмежена раціональність, ризик 


\section{INTRODUCTION}

The market system operates according to objective laws of economy. The patterns of supply and demand interaction, the impact of competition and transaction costs on maximizing profits and expected benefits, rational choice of entities are fundamentally the same at both national and international levels, which makes it possible to use the same theoretical and methodological apparatus. However, some methodological provisions need to be modified according to the realities of existing practice and be verified according to the possibilities of their application in economic phenomena and processes study.

The main methodological provisions of modern economics are reflected in the review publications of such famous scientists as W. Baumol, M. Blaug, K. Arrow, R. Heilbroner $[2 ; 5 ; 16 ; 17]$. Economics, as a specific object of scientific research, requires a separate approach. Its functioning is associated with aspects of uncertainty and risk, limited rationality, information asymmetry, which are reflected in the works of G. Akerlof [1], H. Simon [10], M. Friedman [15] and other famous scientists.

The PURPOSE of the paper is to analyze the main methodological provisions in the context of their application to economics.

\section{RESEARCH METHODS}

Methodological and informational basis of the work is scientific works, the subject of which is economics methodology. Theoretical analysis of methodological principles, their comparison and generalization are used during investigation.

\section{RESULTS}

Current economics is characterized by forming nonuniversal competing methodologies, theories and approaches.

According to I. Lakatos' epistemological scheme [7], the components of scientific paradigm are a set of stable and unchanging postulates of the "hard core", as well as a set of basic prerequisites for the "protective shell", prone to changes within the paradigm. Modern mainstream in economic research corresponds to binary paradigm of neoclassicism and neoinstitutionalism, which are based on two common elements of the "core": 1) methodological individualism; 2) "economic man" conception (homo economicus).

According to individualism methodology, formulated in the works of A. Smith, T. Hobbes, B. Mandeville, $\mathrm{K}$. Menger, economic agents act in accordance with their own interests. Market formations are considered as a set of individuals pursuing their goals. This approach does not mean that human behavior is the same, because the society has a heterogeneous structure, and economic activity is limited by both formal (laws and regulations) and informal factors (traditions, customs, common conventions). In addition, the ways to achieve the goal can differ greatly.

According to "economic man" conception, first formulated by A. Smith and developed in the institutional paradigm, the rational behavior of economic entities (individuals, households, enterprises) is to make such a choice among all possible alternatives that maximize their own benefits by the most effective way [12]. Rational decision is mainly interpreted as thoughtful (i.e. not emotional) and conscious (not intuitive). In this case, methodological principle of rationality is a mandatory component of both dominant paradigms, for which all other principles are adequate. Rationality presupposes the presence of clearly ordered and stable human preferences, which, according to G. Becker, are determined in relation to the basic aspects of life (health, ambition, prestige) [3, P. 27]. The presence of non-traditional criteria for benefits does not deprive them of hierarchy and influences the formation of the individual non-standard behavior.

Rational choice is accompanied by situations of uncertainty and varying degrees of risk regarding the consequences of such activities. In economic theory, uncertainty is often identified with risk, which is partly explained by its polyaspect nature. Further we will use the delimitation of these terms by F. Night, who notes that risk, in contrast to uncertainty, has a quantitative assessment [8, P. 26]. Thus, risk is a measurable uncertainty that is given by a probable way. In choice situations, risk features from the objective point of view are the degree of risk in relation to the inaccuracy of possible consequences assessment, and from the subjective point of view - decisionmakers' attitudes to risk (neutral attitude, risk prevention or addiction).

The focus of the enterprises on maximizing profitability, and households - on benefits, is an axiom of neoclassicism, which implies significant requirements for information quantity and quality. However, the ability of economic agents to perform complex calculations, to identify possible alternatives under information perfection has been constantly criticized for their empirical inconsistency with reality, to which T. Veblen was the first one to pay attention. Even K. Popper acknowledged the limitations of strict rationality postulate [4, P. 351].

In contrast to economic models of maximization, H. Simon, studying the procedures of rational choice, proposed an alternative approach. In particular, he drew attention to impossibility of having all the necessary information, as its optimal amount is always limited by cost, time and compliance with the sample required size [11, P. 63]. At the same time, the scientist noted that the decisions of economic agents are rational only to a certain extent, due to the man's intellectual inability to perceive and evaluate information always adequately, limited analytical abilities of individuals in terms of incomplete knowledge and imperfect computational capabilities: "subjects in the economy try to act rationally, but in fact have this ability only to a limited extent" [14, P. 41].

Investigating the factors of information uncertainty, H. Simon formulated the conception of limited rationality from the economic psychology view, according to which economic agents who are unable to maximize the result, simplify the selection process by making satisfactory decisions [19]. If one of the identified alternatives is compatible with the level of individual's acceptable desires, the search process is stopped immediately. If the obtained results do not match the subject's own expectations, the economic style of behavior is corrected by finding new 
options while reducing their own desires to a realistic level. The main difference between H. Simon's concepttion compared to the classical theories is the shift of emphasis from the results of rational choice (their adequacy to the goals) to the rationality (effectiveness) of the procedures themselves [10, P. 27].

H. Simon, did not contrast the economic theory of rational choice with the behavioral theory of decisionmaking, but complemented them, trying to find common criteria for rationality. Analyzing the universality of the classical hypothesis of maximization, the scientist made an important clarification: when making a choice in the short term to achieve the expected utility or acceptable level of profitability (retention of market share, sales) is a more important motive than long-term maximization; in the long run, a satisfactory level of desires and an achievable maximum are close to coincidence $[11, \mathrm{P}$. 55]. This methodological position is also shared by A. Alchian, who notes that not all entrepreneurs try to maximize profits, but those who are unable to achieve this go bankrupt; therefore, only those entities that maximize their own benefits remain for a long time [18]. In general, the rational behavior of economic agents $\mathrm{H}$. Simon interprets in two ways, agreeing with the compromise option: "people's behavior corresponds to both the procedures of optimality and procedures for obtaining satisfactory results" [10, P. 26].

Other elements of neoclassicism "protective shell" structure, without which it is impossible to formulate economic laws, also include the principles of isolation (study of relatively stable phenomena and processes), aggregation and homogeneity (analysis of typical and representative indicators).

A specific feature of neo-institutional approach is the modification of neoclassical paradigm by preserving basic preconditions of its "core" and the partial transformation of "protective shell" into more perfect, realistic principles. This maintains the key role of institutions, the study of which is carried out through the application of neoclassical economic theory, in particular, using the principle of rational maximization of benefits. In addition, attention is focused on deideologization, the use of quantitative methods of formalization and mathematical modeling.

In contrast to neoclassical theory, neo-institutional economics is based on the following propositions:

1) rejection of the idea of market subjects absolute rationality in favor of the principle of limited rationality (H. Simon) - a key modification;

2) incompleteness, imperfection and asymmetry of information are taken into account (G. Akerlof, J. Stiglitz, M. Spence);

3) denial of the market system ideality due to the dominance of transaction costs (R. Coase, O. Williamson, H. Demsetz);

4) acceptance of economic agents' opportunistic behavior, rather than total subordination to the law (O. Williamson, G. Becker).

Acceptance of limited rationality prerequisites in neoinstitutional paradigm allowed to expand the scope of its research $[3 ; 6 ; 9 ; 13]$. In particular, H. Simon's conception of limited rationality was further developed in the works of O. Williamson, who proposed such a typology of rationality $[14$, P. 40$]$ : "strong" form based on the classical principle of profit maximization; "semi-strong" form limited rationality (in a broader sense than H. Simon's principle of satisfactory decisions); "weak" form - organic rationality (evolutionary approach in economic theory [18]).

O. Williamson applied an identical approach according to another methodological prerequisity - subjective individualism, distinguishing three levels [14, P. 43]: "strong" form - opportunistic behavior of individuals; "semi-strong" form - the motivation of simple (open) desire to satisfy personal interests; "weak" form unselfish behavior (obedience, non-compliance with their own interests).

In neoclassical economic theory, subjects interact with each other in the market in accordance with their own interests and certain generally accepted rules, noncompliance with which is not considered. A number of scientists have paid attention to falsity of such a simplified "mechanistic" order. In particular, Vernon Smith in his Nobel lecture noted that A. Smith in "economic man" doctrine did not claim that all individuals are the same in desire of maximizing utility, because everyone determines their own interest, in their own way [20].

An alternative approach was presented by O. Williamson, introducing the concept of "opportunism": "pursuit of self-interest using cunning, which includes the calculated efforts to stray from the right path, deception, concealment of information and other actions that interfere with interests realization" [13, P. 689]. Opportunistic behavior of economic agents is associated with violations of institutional rules and procedures, both in explicit forms (fraud, theft, fraud) and hidden ones (unfair competition, incorrect interpretation of contractual obligations, use of tax optimization schemes). This type of behavior is primarily inherent in the sphere of shadow economic relations, even in cases where market participants assure that they will refrain from using opportunism. In economics, we consider that methodological combination of Williamson's "semi-strong" limited rationality with the "strong" form of opportunistic behavior is the most significant [14, P. 47].

In the general case, opportunism in O. Williamson's understanding is a source of behavioral uncertainty and leads to the phenomenon of information asymmetry, due to providing partial or distorted information. The prerequisite for completeness and availability of information is one of the least realistic in the context of economic agents' practical activity. In reality, individuals generally do not have a sufficient amount of necessary information, which is the subject of choice for rational decisions. In addition, it is quite common for some market participants to be more aware than others. Therefore, economic agents, acting mainly in conditions of limited and asymmetry of information, try to avoid such situations by searching for new data, which leads to increased transaction costs.

The problems of information quality, its ambiguity and asymmetry are reflected as an object of study in the theory of information economy by G. Akerlof, J. Stiglitz and M. Spence. In particular, G. Akerlof showed that information asymmetry provokes the phenomenon of inverse or negative selection, resulting in an increase in market share of lower quality goods [1]. J. Stiglitz, in turn, proved that the prerequisite for uniform distribution of information is wrong, because it distorts economic reality of market imperfections [21]. 
Limited rationality, information asymmetry and fundamental uncertainty in the form of risk are determinants of transaction costs. Neo-institutionalists include also any expenditure on economic system management, accompanied by a counter exchange of resources and payments: search for information, protection of property rights, negotiation, execution of contracts, and so on. D. North explains economic feasibility of various institutions by the need for reducing transaction costs [9, pp. 84-94]. He concludes that the need for new institutions arises when it is impossible to maximize benefits within the existing system.

\section{CONCLUSIONS}

Neoclassical paradigm in economic research is based on methodological individualism, rational behavior of market participants, stability of individuals' certain preferences, isolation and aggregation. A distinction should be made between rationality of economic activity as a process and its efficiency as a result. Generalization of different approaches of a number of scientists makes it possible to make a conclusion about the practical acceptability of economic agents rational behavior in general. However, this does not mean that such behavior is based on absolute calculations, full awareness and is aimed at optimazing the choice, especially in conditions of risk.

Modern economic paradigm formulates methodological prerequisite for rationality both in the classical variant (the principle of maximization) and in the "soft" form of limited rationality (satisfaction of individuals with an acceptable level of their own aspirations). Maximization (expected utility or profitability) is not the only and universal criterion of rationality, but remains the most common in practical application. Even with the limited rationality of economic agents, the process of choosing the best alternative among the available ones takes place.

Methodology of neo-institutional economic paradigm is based on the principles of limited rationality, information imperfection and opportunistic behavior of economic agents. Thanks to introduction of modified preconditions and methodological principles into neo-institutionalism, it became possible to improve the analysis of economics and better interdisciplinary research in combination with the approaches of other branches of science.

\section{References}

1. Akerlof Dzh. Market «lemons»: quality uncertainty and the market mechanism. THESIS. 1994. № 5. pp. 91-104. (in Russian).

2. Baumol U. What did not know Alfred Marshall: XX century contribution to economic theory. Economic Issues. 2001. № 2. pp. 73-107. (in Russian).

3. Bekker G.S. Economic analysis and human behavior. THESIS. 1993. Issue 1. pp. 24-40. (in Russian).

4. Blaug M. Methodology of Economics, or as economists explain. Moscow: Economic Issues, 2004. 416 p. (in Russian).

5. Blaug M. 100 great economists after Keynes. Saint Petersburg: Economy school, 2008. 384 p. (in Russian)

6. Kouz R. Firm, the market and the right. Moscow: New publishing, 2007. 224 p. (in Russian).

7. Lakatos I. The methodology of scientific research programs. Philosophy Issues. 1995. № 4. pp. 135-154. (in Russian).

8. Nait F. The concepts of risk and uncertainty. THESIS. 1994. № 5. pp. 12-28. (in Russian).

9. Nort D. Institutions, Institutional Change and Economic Performance. Moscow: Nachala, 1997. 180 p. (in Russian).
10. Saymon G.A. Rationality as process and product of thought. THESIS. 1993. № 3. pp. 16-38. (in Russian).

11. Saymon G.A. Decision theory in economics and the science of behavior. Milestones of Economic Thought. Saint Petersburg: Economy school, 2000. Vol. 2. pp. 54-72 (in Russian).

12. Samuelson P.E. Maximization principle in economic analysis. THESIS. 1993. № 1. pp. 184-202. (in Russian).

13. Uilyamson O. Economic Institutions of Capitalism: Firms, Markets, "relational" contracting. Saint Petersburg: Lenizdat, CEV Press, 1996. 702 p. (in Russian).

14. Uilyamson O. Behavioral assumptions of modern economic analysis. THESIS. 1993. № 3. pp. 39-49. (in Russian).

15. Fridmen M. Methodology of Positive Economics. THESIS. 1994. № 4. pp. 20-52. (in Russian).

16. Haylbroner R.L. Economic theory as a universal science. THESIS. 1993. № 1. pp. 41-55. (in Russian).

17. Errou K. Development of economic theory since 1940: an eyewitness view. Economic Issues. 2010. № 4. pp. 4-23. (in Russian).

18. Alchian A. Uncertainty, Evaluation and Economic Theory. Journal of Political Economy. Los Angeles, 1950. Vol. 58. № 3. pp. 211-221.

19. Simon H.A. A Behavioral Model of Rational Choice. Quarterly Journal of Economics. 1955. Vol. 69. № 1. pp. 99-118.

20. Smith V. Nobel Prize Lecture: Constructivist and Ecological Rationality in Economics. Stockholm University, 2002. URL: http://www.nobelprize.org/nobel_prizes/economicsciences/laureates/2002/smith-lecture.html.

21. Stiglitz J.E., Grossman S.J. Information and Competitive Price Systems. The American Economic Review. 1976. Vol. 66. № 2. pp. 246-253.

\section{Список використаних джерел}

1. Акерлоф Дж. Рынок «лимонов»: неопределенность качества и рыночный механизм. THESIS. 1994. Вып. 5. C. 91-104.

2. Баумоль У. Чего не знал Альфред Маршалл: вклад $\mathrm{XX}$ столетия в экономическую теорию. Bопросы экономики. 2001. № 2. C. 73-107.

3. Беккер Г.С. Экономический анализ и человеческое поведение. THESIS. 1993. Вып. 1. С. 24-40.

4. Блауг М. Методология экономической науки, или как экономисты объясняют. М.: НП «Журнал Вопросы экономики», 2004. $416 \mathrm{c}$.

5. Блауг М. 100 великих экономистов после Кейнса. Спб.: Экономическая школа, 2008. 384 с.

6. Коуз Р. Фирма, рынок и право. М.: Новое издательство, 2007. $224 \mathrm{c}$.

7. Лакатос И. Методология научных исследовательских программ. Вопросы философии. 1995. № 4. С. 135-154.

8. Найт Ф. Понятия риска и неопределенности. THESIS. 1994. Вып. 5. С. 12-28.

9. Норт Д. Институты, институциональные изменения и функционирование экономики. М.: Фонд экономической книги «Начала», 1997. 180 с.

10. Саймон Г.А. Рациональность как процесс и продукт мышления. THESIS. 1993. Вып. 3. С. 16-38.

11. Саймон Г.А. Теория принятия решений в экономической теории и науке о поведении. Вехи экономической мысли.. СПб.: Экономическая школа, 2000. Т. 2. С. 54-72.

12. Самуэльсон П.Э. Принцип максимизации в экономическом анализе. THESIS. 1993. Вып. 1. С. 184-202.

13. Уильямсон О.И. Экономические институты капитализма: фирмы, рынки, "отношенческая" контрактация. СПб.: Лениздат, CEV Press, 1996. 702 c.

14. Уильямсон О.И. Поведенческие предпосылки современного экономического анализа. THESIS. 1993. Вып. 3. С. 39-49.

15. Фридмен М. Методология позитивной экономической науки. THESIS. 1994. Вып. 4. С. 20-52. 
16. Хайлбронер Р.Л. Экономическая теория как универсальная наука. THESIS. 1993. Вып. 1. С. 41-55.

17. Эрроу К. Развитие экономической теории с 1940 года: взгляд очевидца. Вопросы экономики. 2010. № 4. С. 4-23.

18. Alchian A. Uncertainty, Evaluation and Economic Theory. Journal of Political Economy. Los Angeles, 1950. Vol. 58. № 3. pp. 211-221.

19. Simon H.A. A Behavioral Model of Rational Choice.
Quarterly Journal of Economics. 1955. Vol. 69. № 1. pp. 99-118. 20. Smith V. Nobel Prize Lecture: Constructivist and Ecological Rationality in Economics. Stockholm University, 2002. URL: http://www.nobelprize.org/nobel_prizes/economicsciences/laureates/2002/smith-lecture.html.

21. Stiglitz J.E., Grossman S.J. Information and Competitive Price Systems. The American Economic Review. 1976. Vol. 66. № 2. pp. 246-253. 